\title{
Impact of Pre and Post Bank Consolidation on the Growth of Nigeria Economy
}

\author{
Nwankwo, Odi. Fcib ${ }^{1}$ \\ ${ }^{1}$ Department of Banking and Finance, Kogi State University, Anyigba Kogi, Nigeria \\ Correspondence: Nwankwo, Odi. Fcib, Department of Banking and Finance, Kogi State University, Anyigba \\ Kogi, Nigeria. Tel: 234-803-576-3229. E-mail: Odinwankwo2002@Yahoo.com
}

Received: January 18, 2013

Accepted: April 8, 2013

Online Published: June 17, 2013

doi:10.5539/ijbm.v8n13p73

URL: http://dx.doi.org/10.5539/ijbm.v8n13p73

\begin{abstract}
The bank consolidation programmes required banks in Nigeria to employ various strategies organic or Merger and Acquisition to consolidation their capital base. This study empirically analyzed the impact of pre and post bank consolidation on the growth of Nigerian economy using T-test. The study observed that post bank consolidation have significant positive effect on the growth of Nigeria economy; pre bank consolidation has positive and insignificant effect on economic growth. The implication of the study are the Merger and Acquisition growth strategy results in superior economic growth and that pre bank consolidation is not significant to economic growth. The study recommended that subsequent upward review of capital base should be done mainly by way of Merger and Acquisition) and that banks should boost profitability through effective intermediation and investment diversification.
\end{abstract}

Keywords: consolidation, economic growth, financial stability, capital base, efficiency, profitability, safe banking sector

\section{Introduction}

Over the years, Nigerian banking sector reforms has aimed at improving the stability of Nigerian economy. This reformation started in 2004 when Central Bank of Nigeria (CBN) announced that banks operating in Nigeria had to consolidate their capital base to $\$ 25$ billion. Before the reform, there were 89 commercial banks operating in Nigeria which have an interesting size and a very high degree of soundness. Structurally, Nigerian commercial banks were highly concentrated and accounted for about $50 \%$ of the industry's total assets and liabilities (Ezeoha, 2007). Most banks in Nigeria operated with a capital base of less than $\$ 10$ million before 2004. The largest bank in Nigeria as of 2004, had a capital base of about US\$240million compared to the US\$526million for the smallest bank in developed countries which its asset base is larger than all of the Nigerian commercial banks put together (Ezeoha, 2007 and Adekoya and Oyatoye, 2007).

Soludo (2004) opined that the problems facing most of the Nigerian banks include persistent illiquidity, poor asset quality and unprofitable operations. Nigerian banks seemed whole dependent on government and government owned parastatals. The implications of Soludo's view were that the resources of such banks can not contribute to the growth of the economy, making their operations highly vulnerable to savings in government revenue which is arising from the uncertainties of the international market.

Against this background, the Central Bank of Nigeria introduced a minimum capitalization base for banking institutions to meet up the demand of the customers. Full compliance was required before the end of year 2005, with a view to enhancing bank efficiency, size and developmental rates. The banking reform required banks in Nigeria to have a minimum capital based of \#25billion. This shows that a number of existing banks had to consolidate their capitalisation through Merger and Acquisition. Affected banks were therefore required to make strategic decisions on how to consolidate.

Consolidation can be defined as an act of merging many things into one. In finance, consolidation is similar to merger. In a merger, if firm A buys firm B, the surviving firm is the buyer, A and when A and B consolidated, a new firm C is created. (Adegbaju \& Olokoyo, 2008). As of 2012, banking consolidation exercise has produced 21 commercial banks out of the 89 banks which hitherto have been in existence in Nigeria before 2004. In the same year 2012, other banking sector reforms like the take-over of banks (Spring bank, Bank PHB and Afribank now 
Enterprise Bank, Keystone Bank and Mainstreet Bank respectively) by government and recent development of mergers among few banks, which Access bank is one of them.

The major objectives of banking sector consolidation or reforms are to increase intermediation process, ensure financial sector stability, promote economic growth, increase the capital base of banks, enhance liquidity and capitalization of stock market, enhance expansion of shareholders base to promote good corporate governance, facilitate evolution of strong and safe banking system, ensure efficiency in risk management and bank operation, and to ensure healthy domestic and cross-border competition (Soludo, 2005).

With regards to banking sector reforms, the assumption is that banking sector liberalization accompanied by increased capital base requirements is a necessary condition for improved performance of the banking sector. The underlying argument is that increased capital base may imply increase liquidity and availability of loanable funds which should lead to fall in interest rate, thereby stimulating demand following response as envisaged in Say's Law of market which states that supply creates its own demand in the market (Jhinghan, 2003). Unfortunately, the consolidation exercise in Nigeria which is believed to have drawn a significant proportion of currency outside banks and new monies from both the domestic and international money markets into Nigerian banks, may not have had significantly effect on the increased credit to the real sector of the economy. This is not in the opinion of the financial analyst that banking sector consolidation should enhance the ability of banks to create more credits to investors (Somoye, 2008). This study focused on the implications of pre and post bank consolidation on economic growth in Nigeria from 2000 to 2011 with a view to determining the efficiency and profitability of the consolidation approaches adopted by the banks. This section one is followed by section two which is the review of empirical and theoretical literature on bank consolidation; section three discusses the models and methodology while section four provides data and empirical evidence and the final section which is section five provides the summary, conclusion and recommendations of the study.

\section{Review of Related Literature}

\subsection{Theoretical Framework}

Based on the important nature of this work, it is anchored on two theories which is Say's Law and Concentration Theory.

\subsubsection{Say's Law Theory}

This theory believes that recapitalization of banks leads to increased capital base which may imply increase availability of loanable funds to the economy. This should lead to a fall in interest rate and should be capable of stimulating or eliciting a demand following response as envisaged by Say's Law of markets. While Say's Law remained silent with regard to the role of money, it however argues that the only reason to have money is to buy goods; hence this theory did not envisage the Keynesian outcome that there could be the precautionary and speculative demand for money (Kates, 1998).

This argues that the premise of the financial sector recapitalization appears to be consistent with the classical view of monetary policy that the main function of money is to act as a medium of exchange while its importance is to determine aggregate price level.

\subsubsection{Concentration Theory}

This is the theory that explains the degree of control in which larger firms have on economic activities in the country (Sathye, 2002). This theory argues that economies of scale bring about bank merger and acquisition so that concentration will be based on bank efficiency (Demirguc-kunt and Levine, 2000). Some theoretical arguments believed that less concentration on banking industry with small size bring about financial crisis in banking sector then the large banks (Allen and Gale, 2000; and Beck, Demirguc-Kunt and Levine, 2004).

Supporters of this theory argue that large banks can grow faster and as well enhance profitability the smaller banks then the small banks. Based on the above theory, small banking industry is easy to monitor than those large banks because corporate control of banks will be more effective (Beck, Demirguc-Kunt and Levine, 2004).

\subsection{Empirical Studies}

Adegbagu and Olokoyo (2008) used descriptive research design (Mean and Standard Deviation) and t-test and test of equality mean analytical techniques to study the effect of recapitalization on bank's performance on Nigerian banks. The study found out that the means of bank profitability ratios such as the Yield on Earning Asset (YEA), Return on Equity (ROE) and Return on Assets (ROA) were significant. This means that there is statistical indifference between the mean of the pre and post 2004 bank recapitalization.

Somoye (2008) examined the performance of government induced banks consolidation and macro-economic 
performance in Nigeria in a post consolidation period. He found out that bank consolidation may not necessarily be a sufficient tool for financial system stability and sustainable development. The study posits that consolidation programme has not improved the overall performance of banking industry significantly and also has contributed little to the growth of the real sector for sustainable development.

Umah (2009) used exploratory research design and multiple regression analysis to study the impact of banking industry recapitalization on employment in Nigerian banks. The study revealed that shareholders funds, Total Assets and number of domestic branches caused $62 \%$ of employment in the banking industry. This, recapitalization led to increase in employment in the Nigeria banking industry from 2006 up to 2008 .

Ezeoha (2007) studied the structural effects of banking industry consolidation in Nigeria-A review and notes that the ongoing banking industry consolidation in Nigeria represents the latest attempt by the CBN to solve the problem of bank distress and failure, and to reposition the industry for national and global economic challenges. The study finds that some of the operational difficulties facing the banks even before consolidation are external to them and are still prevalent in the Nigerian economy. The study concludes that consolidation alone cannot be seen as the solution to the problem of the industry, unless the background economic difficulties such as the weak state of the national economy, deplorable state of the infrastructure and the decreasing level of public confidence in the overall economic and financial reforms going on in the country is addressed, the expected benefits of consolidation may be hard to realize.

Samuel (2010) in a study of recent banking sector reforms and economic growth in Nigeria using ordinary least square regression techniques. The result established that interest rate margins, parallel market premiums, total banking sector credit to the private sector, inflation rate, size of banking sector capital and cash reserve ratios account for a very high proportion of the variation in economic growth in Nigeria. This shows that there is a strong and positive relationship between economic growth and banking sector reforms in Nigeria.

Olufayo (2011) used questionnaire to investigate Nigeria bank consolidation exercise and plight of female employees. The study revealed that the removal of conditionality's for bankers would not affect productivity much because it kicks against boosting the moral staff.

Bakare (2011) used Sample Test techniques and E-view statistical packages to analyze the trend and growth implication of bank consolidation in Nigeria. The study revealed that banks are more adequately capitalized and are less risky after the programme. It also revealed that recapitalization has low but significant influence on the growth of Nigerian economy. The study used quasi - experimental research design approach in data analysis.

Kehinde and Kareem (2012) studied effect of pre and post bank consolidation on the accessibility of finance to small and medium enterprises in Nigeria using ordinary least square. It was found that banks' consolidation has failed to foster a vibrant and competitive SMEs sector that would enhance job creation and economic growth in Nigeria. This means that for SMEs to play its role in the development of the economy during pre and post consolidation, government intervention is needed.

\subsection{History of Recapitalization in Nigeria}

The recent call for recapitalization in the banking industry has raised much argument among the bank regulators, promoters and depositors as if shoring up of bank's capital base is a new phenomenon. Historically, in 1958 after the first banking ordinance in 1952, the Colonial government then raised the capital requirement for banks especially the foreign commercial bank from 200,000 pounds to 400,000 pound. Ever since then, the issue of bank recapitalization have been a continuous phenomenon not only in Nigeria but generally around the world especially as the world continues to witness increasing interdependence among national economies (Adegbaju and Olokoyo, 2008). According to Adegbaju and Olokoyo (2008) since 1969 in Nigeria, recapitalization has been on the increase depict the level of bank operation in Nigeria. In 1969, recapitalization for banks in Nigeria was N1.5million for foreign banks and N600,000 for indigenous banks. In 1979 it was N2million for commercial banks and Merchant banks respectively, though it was raised up to N10million and N6million in October 1988. From 1989 to July 2004 and 2005, recapitalization has been from N20million and N12million for Commercial and Merchant banks to N25billion and N30billion respectively.

\subsection{Review of Corporate Strategies to Achieve Minimum Capital Base of N25 Billion in Nigeria}

The emergency of bank consolidation in Nigerian banking sector during the year 2004 and 2005 bring about the reduction of the number of Nigerian deposit money banks to 25 as at December 31, 2005 and further reduced to 24, through merger and acquisition in 2008. Strategies adopted by banks to achieve the stipulated minimum capital base of N25billion during the banking sector consolidation of 2004 and 2005 include Mergers and Acquisition (Adekoya and Oyatoye, 2007). 


\subsection{Bank Consolidation and Nigerian Economy}

The directive by the CBN that banks should raise their capital base to N25billion has several implications for both the banking industry and the Nigerian economy at large. The implication are categorised into two parts namely; brand and structural implications (Somoye, 2008).

Brand Implication: With regards to branch implications, the new entities that will come from the dust of consolidation will need to deal with brand-related issues such as: change of bank name if two or more banks merges together and decides not to adopt any of the participating banks name; change and adoption of acceptable bank logos; evolution and acceptance of a new brand culture for emerging banks; evolution of acceptable brand message; and the challenge of Information Communication Technology (ICT) that will meet up customers demand and the competitive business environment.

Structure Implication: The recapitalization of banks will leave in its wake, a number of structural issues which will have direct impact on staff, customers and the entire banking sector. They include: the reduction in the number of banks in the country; the closure of many small banks, especially those in the rural area with poor capital deposit, increased competition due to better incentives and rendering of bank services; acquisition digestion issues which will include loss of jobs, consolidation of branch locations and tackling of inefficiencies and bureaucracies; and reconstitution of management and board of the banks.

\subsection{Prospects of Bank Recapitalization in Nigeria}

The prospects are as follows (Somoye, 2008):

1) It is expected that the initial public offering (IPO) by banks through the capital market will likely increase the level of financial deepening as evidenced in the upsurge in the volume and value of trading in the stock market.

2) The reform in the banking sector has the potentials to attract more foreign investment inflow, especially in the area of portfolio investment, which if sustained will boost the level of economic activities especially toward non oil sector.

3) The consolidation of banks is likely to attract a significant level of foreign banks entrance into Nigeria which will become a feature in the industry over time.

4) The recapitalization exercise will bring about more confidence by the international community of the banking sector thereby attracting more foreign investment into the country.

5) As the level of financial intermediation increases, interest rate is likely to fall thereby increase lending to the real sector which will translate to employment generation and robust economic growth.

6) It is likely to enthrone efficiency in cost of operation, risk management and profitability.

\subsection{Types of Mergers and Acquisition}

In literature on merger, consolidation and acquisition are frequently used in a loose sense to refer to a situation in which firms are integrated in some form. A merger occurs when one firm obtains the assets and liabilities of another firm for a certain price. The selling firm ceases to exist as a separate entity; only the buying firm survives. A consolidation is similar to merger. In a merger, if firm A buys firm B, the surviving firm is the buyer, A and when $\mathrm{A}$ and $\mathrm{B}$ consolidated, a new firm $\mathrm{C}$ is created. There are three types of merger and acquisition as recognised by many researchers. They are as follows: Horizontal, Vertical, and Conglomerate mergers. However, Gaughan (2007) mention and discussed the fourth type of merger and acquisition, which is Concentric mergers.

Vertical Merger: This is a situation when two firms achieve a successive functional relationship. That is when the output of one firm is a production input for or is marketed by the other firm.

Conglomerate Mergers: A Conglomerate Merger occurs between firms whose products are unrelated and they are situated at different production stages.

Concentric Merger and Acquisition: This type of merger involves firms that have different business operation patterns, but may be highly related in production and distribution technologies.

Horizontal Merger and Acquisition: This is a merger that occurs between firms whose products are substitutes. The purpose of this type of merger is to eliminate a competitor company, to increase market share, buy up surplus capacity or obtain a more profitable firm in order to gain a competitive advantage. 


\section{Methodology}

\subsection{Model Estimation and Analysis}

In an attempt to test the significance of pre and post bank consolidation on economic growth in Nigeria, the study used a T-test which is the best tool for comparison, using money supply, exchange rate, interest rate and inflation to evaluate the impact of pre and post bank consolidation on the economic growth in Nigeria spanning from 2000 to 2011.

Adegbaju and Olokoyo (2008), Somoye (2008), Bakare (2011) and Kehinde and Kareem (2012) used the same model and it was modified to agree with our work by using only money supply, exchange rate, and interest rate to enable the study examine the functional relationship between pre and post bank consolidation and economic growth in Nigeria.

The model can be expressed in multiple linear regression equation form:

$$
Y=a+b x
$$

Where:

$\mathrm{Y}=$ Dependent variables (performance ratios).

$\mathrm{a}=$ Intercept parameters (where the regression surface crosses the Y-axis).

$\mathrm{b}=$ Slope of the regression line.

$\mathrm{x}=$ Independent variable (capital base).

Applying the above simple linear regression equation to our study, we have:

$\mathrm{GDP}=\mathrm{f}(\mathrm{MS}$, Exrate, Intrate).

$\mu_{\mathrm{t}}=$ Error term at periods.

$\alpha=$ Constant of the model.

$\beta=$ Coefficient of the parameter.

Hypotheses:

$\mathrm{Ho}_{1}$ : The level of pre bank consolidation no significant positive impact on economic growth in Nigeria.

$\mathrm{Ho}_{2}$ : The level of post bank consolidation has no significant positive impact on economic growth in Nigeria.

\section{Estimation of Results}

\subsection{Unit Root Test}

The Augmented Dickey-Fuller (ADF) unit-root test was employed to test for stationarity or the existence of unit roots in the data. The result of the tests judging by the Augmented Dickey-Fuller (ADF) test statistic, R-Squared and Durbin-Watson statistic at 5\% and 10\% critical values reveals that all the variables are non-stationary at level but stationary at first differencing. The results of the unit-root tests are presented below:

Table 1. Unit root result augmented dickey-fuller unit root test trend and intercept

\begin{tabular}{cccccc}
\hline Variable & ADF Test Statistic & $5 \%$ critical values & $10 \%$ critical values & Order & Remark \\
\hline GDP & -5.614849 & -3.029970 & -2.655194 & $1(1)$ & Stationary \\
M2 & -5.111647 & -3.052169 & -2.666593 & $1(1)$ & Stationary \\
INTRATE & -8.047718 & -3.065585 & -2.673459 & $1(1)$ & Stationary \\
EXR & -3.886932 & -3.029970 & -2.655194 & $1(1)$ & Stationary \\
\hline
\end{tabular}

Source: E-view 7.0.

The above empirical test shows that GDP, M2, INTRATE AND EXR are integrated of order one. They are integrated of the same order; From the above tables 1, it was discovered that ADF with trend and intercept are integrated of the same order. Considering the ADF test statistics at $5 \%$ and $10 \%$ critical values, it is observed that test statistics are greater than the critical values. Thus, the series are said to be stationary at that first difference.

\subsection{Co-Integration Test}

Co-integration test is used to test for the long run relationship between dependent and independent variables. From the table 2 below, there is a long run relationship between the real gross domestic product (dependent variable) 
and the explanatory variables (GDP, M2, INTRATE and EXR) in Nigerian within the period under study 2000-2011. Firstly, the summary of the Johansen Co-integration test indicates that the explanatory variables, M2, INTRATE and EXR are co-integrated of order one. This means that the test below indicates one co-integrating equation at $5 \%$ level of significance. The model with lag 1 was chosen with the linear deterministic test assumption. The variables can therefore be said to have reliable long-run relationship among them with dependent variable coefficient of co-integration of 0.787432. Johansen co-integration test for the series; GDP, M2, INTRATE and EXR are presented in Table 2 below.

Table 2. Co-integration result

\begin{tabular}{lllll}
\hline Eigenvalue & Trace Statistic & 0.05 critical value & Prob.** & Hypothesized No. of CE(s) \\
\hline 0.787432 & 30.99104 & 29.79707 & 0.0000 & None \\
0.674352 & 14.89455 & 12.654789 & 0.0000 & At most 1 \\
0.576389 & 4.954545 & 3.841466 & 0.0000 & At most 2 \\
0.456323 & 2.786543 & 1.342587 & 0.0000 & At most 3 \\
\hline
\end{tabular}

Note: *denotes rejection of the hypothesis at $5 \%$ significance level. L.R test indicates 1 co-integrating equation(s) at $5 \%$ level of significance.

Under the Johansen co-integration test, it is observed that there are one co-integrating equations. In Johansen's Method, the eigenvalue statistic is used to determine whether co-integrated variables exist. Co-integration is said to exist if the values of computed statistics are significant different from zero. The Trace Statistics is higher than 5\% critical value and the eigenvalue are found as $(0.787432,0.674352,0.576389$ and 0.456323$)$. The Trace Statistics of GDP, M2, INTRATE and EXR are greater than the critical value at both 5\% level of significance. Also, the Eignvalues of GDP, M2, INTRATE and EXR are significantly greater than zero. In other words, the null hypothesis of no co-integration among the variables is rejected in at least one equations. The test result shows the existence of a long-run equilibrium relationship in one co-integrating equations at $5 \%$ significance level.

The Nigeria's economic growth is affected by pre and post bank consolidation. Therefore, money supply with other specified variables in the model, changes the GDP value and the propensity to grow.

Worthy of note is the sign borne by the coefficient estimate of Money Supply. Regarding determinants of Money Supply, the supply of money is determined by the behaviour of three economic factors:

1) The behaviour of banks concerning the amount of reserves that they decide to keep at any point in time.

2) The behaviour of the non-bank public in dividing their money assets between currency and demand deposits. This is because the larger the non-bank public's marginal currency-deposit ratio, the smaller will be the expansion of deposits.

3) The Central Bank of Nigeria in their decision to change the size of high-powered money (money base and also the right of the authorities to set the legal reserve ratio).

The decrease in the money supply could be attributed to the policy adopted by the CBN to curb high inflation in the economy during the period of bank consolidation. The control of demand-pull inflation with respect to decrease in money supply implies reduction in government expenditure, increase in personal and company taxes and regulation of money supply and inflation by deposit money banks. Increase in money supply and exchange rate by deposit money banks during post bank consolidation has the effect of increasing the quantity of money in circulation leading to excess demand and consequently increase in prices of goods and services.

Another note to be taken is the high value of the coefficient of interest rate (INTRATE) and its negative sign. A good monetary policy will oppose the activities on the increase and fluctuation in interest rates during pre-consolidation. Increase in interest rate means increase in the cost of borrowing i.e increase in the cost of capital. Such increase in the cost of capital increase the total cost of production and lead to increase in the prices of final products.

\subsection{Error Correction Model (ECM)}

The existence of long-run co-integrating equilibrium provides for short fluctuations. In order to straighten out or absolve these fluctuations, an attempt was made to apply the Error Correction Model (ECM).

As noted, the ECM is meant to tie the short-run dynamics of the cointegrating equations to their long-run static dispositions. Below is the ECM test for the given data during pre and post bank consolidation: 
Table 3. ECM result for pre-consolidation

\begin{tabular}{lllll}
\hline Variable & Coefficient & Std. Error & t-Statistic & Prob. \\
\hline C & -2.099728 & 4.885648 & 0.429775 & 0.6728 \\
M2 & -0.015667 & 0.030161 & 0.519455 & 0.0606 \\
INTRATE & 0.170965 & 0.227016 & 0.753094 & 0.0000 \\
EXR & 0.063035 & 0.017318 & 0.639924 & 0.0020 \\
\hline
\end{tabular}

R-squared $=0.455679$.

Source: E-View 7.0.

Table 4. ECM result for post-consolidation

\begin{tabular}{|c|c|c|c|c|}
\hline Variable & Coefficient & Std. Error & t-Statistic & Prob. \\
\hline $\mathrm{C}$ & 3.134257 & 2.342765 & 2.429661 & 0.0000 \\
\hline M2 & 0.715013 & 0.130162 & 3.519455 & 0.0021 \\
\hline INTRATE & 0.270964 & 0.227016 & 2.753094 & 0.0000 \\
\hline EXR & 0.563035 & 0.217319 & 3.534674 & 0.0000 \\
\hline
\end{tabular}

R-squared $=0.852345$.

Source: E-View 7.0.

The figures from the ECM of pre and post bank consolidation are quite revealing. That is, the coefficient estimates of the constant and explanatory variables have alternated their signs as against the long-run relationship found in the normalized co-integrating equation. This shows exactly what is needed to be done in order to absolve the short-run dynamics of relationships. Again, the significance of ECM holds that a negative and statistically significant error correction model coefficient is a necessary condition for the variables to be co-integrated.

From the table above, the calculated t-test in pre bank consolidation is observed to be $0.519455,0.753094$, and 0.639924 while post bank consolidation is $3.519455,2.753094$ and 3.534674 for money supply, interest rate and exchange rate respectively as attitude of pre and post bank consolidation. Thus, the t-calculated value of pre bank consolidation is not significant because it is less than the critical t-value of 1.71 and at 0.05 level of significance. While in post bank consolidation, our obtained or calculated value of t-test lies outside the range of 1.71. This means that post bank consolidation has a significance impact on the growth of Nigerian economy than pre bank consolidation.

Finally, the results of the study do provide support for the hypotheses that post bank consolidation have a significant impact on the growth of Nigerian economy.

\section{Summary, Conclusion and Recommendations}

\subsection{Summary of Findings}

This study focused on the impact of pre and post bank consolidation on the growth of Nigerian economy with a view to ascertaining whether merger and Acquisition or organic growth strategy to bank consolidation. The results obtained using the T-test analysis indicated that pre bank consolidation have insignificant positive effect on the growth of Nigerian economy and that post bank consolidation have positive and significant effect on economic growth in Nigeria.

\subsection{Conclusion}

This study concluded that Merger and Acquisition strategy to bank consolidation resulted in superior bank performance in terms liquidity, profitability and asset quality which will in turn encourage the growth of the economy while organic growth results in superior bank performance in terms of Capital Adequacy and return on investment (investment valuations).

The study also concluded that a significant positive impact exist between post bank consolidation and economic growth in Nigeria. Pre bank consolidation has positive but insignificant effect on economic growth.

The major policy implication of this analysis are that Merger and Acquisition growth approach to bank consolidation result in superior economic growth and that pre bank consolidation is not significant to economic growth in Nigeria because of its negative effect on bank profitability. 


\subsection{Recommendations}

The study recommends as follows:

1) Policy framework and initiatives should be strengthened in the areas of quality bank management, supervision and control by the Central Bank of Nigeria and the Federal Government to ensure consistency in policy objectives and instruments through good implementation strategy to boost economic growth.

2) Bank consolidation should be reviewed upward from time to time to sustain the stability and performance of the banking industry and economy.

3) To boost profitability, banks should diversify their investment with more of it on long-term basis and as well integrate the informal financial services sector through effective intermediation process to increase the growth of Nigeria economy.

4) We recommended that subsequent bank consolidation should be done by way of Merger and Acquisition knowing fully well the implication of raising fund through the capital market.

\section{References}

Access Bank. (2011). Annual report 2011. Retrieved from http://www.accessbankplc.com

Adegbaju, A., \& Olokoyo, F. (2008). Recapitalization and Bank Performance: A Case Study of Nigeria Banks. African Economic and Business Review, 6(1), 1-16.

Adekoya, A., \& Oyatoye, E. (2007). Determining the strategic Consolidation of the Capital Base of Nigerian Commercial Bank. International Journal of Project Management, 19, 19-25.

Adeyemi, K. S. (2005). Banking sector consolidation in Nigeria: Issues and Challenges. Retrieved from http://www.unionbanking.com

Al-Faki, A. (2005). Bank re-capitalization and The Nigeria Stock market. Nigeria Securities and Exchange commission quarterly Bulletin.

Allen, F., \& Gale, D. (2003). Macroeconomic Theory (11th ed.). Delhi.

Bakare, A. S. (2011). The Trend and Growth Implications of Bank Recapitalization in Nigeria. African Journal of Business Management, 5(14), 5938-5945.

Balogun, E. D. (2007). A Review of Soludo's Perspective of Banking Sector Reforms in Nigeria. Munich Personal REPEC Archive, 1-21.

Cartwright, S., \& Cooper, C. (1992). Managing Mergers and Strategic Alliances.

CBN. (2005). Annual Report for the year ended 31 December, 2005. Retrieved from http://www.cenbank.org

Coffee, J. C. (1988). Shareholders versus Managers: The strain in the corporate web. In J. C. Coffe, L. Lowestein \& S. Rose-Ackerman (Eds.), Knights, Raiders and Targets: The Impact of the Hostile takeover (p. 134). Oxford, Oxford University Press.

Cuesta, R. A., \& Orea, L. (2002). Mergers and technical efficiency in Spanish savings banks: A stochastic distance function approach. Journal of Banking and Finance, 26, 2231-2247. http://dx.doi.org/10.1016/S0378-4266(01)00184-4

Demirgu C-Kunt, A., \& Levine, R. (2000). Bank Concentration: Cross Country Evidence. Retrieved from http://www.globalpolicy.org

Demirgu C-Kunt, A., \& Levine, R. (2004). Bank Concentration and Fragility: Impact and Mechanics. Retrieved from $\mathrm{http} / / / \mathrm{ww}$.nber.org

Denrell, J., Fang, C., \& Winter, S. G. (2003). The economics of strategic opportunity. Strategic Management Journal, 24(10), 977-990. http://dx.doi.org/10.1002/smj.341

Ezeoha, A. (2007). Structural Effects of Banking Industry Consolidation in Nigeria: A Review. Journal of Banking Regulation, 8, 159-176. http://dx.doi.org/10.1057/palgrave.jbr.2350044

Gaughan, P. A. (2007). Mergers, Acquisitions, and Corporate Restructurings (4th ed.). New Jersey: John Wiley \& Sons, Inc.

Hirtle, B. (1991). Factors Affecting the Competitiveness of International Active Financial Institution, Federal Reserve Bank of New York. Quarterly Review Spring, 38-51.

Houston, J. F. (2001). Where do merger gains come from? Bank mergers from the perspective of insiders and 
$\begin{array}{llll}\text { outsiders. } & \text { Journal } & \text { 285-331. }\end{array}$ http://dx.doi.org/10.1016/S0304-405X(01)00046-0

IBTC. (2007). Corporate Finance. Retrieved from http://www.ibtc.com

Kates, A. (1998). Says Laws and the Keynesian Revolution: How Macroeconomic Theory Lost its Way. Edward Elgard Publishing Limited.

Kennedy, P. (2003). A Guide to Economic (5th ed.). Cambridge: the MIT Press.

Mirhkin, F. S. (2006). The Economic of Money, Banking and Financial Market (8th ed.). London, Addison-Wesley.

Mitchell, M., \& Mulherin, J. H. (1996). The impact of industry shocks on takeovers and restructuring activity. Journal of Financial Economics, 41, 193-229. http://dx.doi.org/10.1016/0304-405X(95)00860-H

Mordi, C. N. (2004). Institutional framework for the regulation and supervision of the financial sector. Central Bank of Nigeria Bullion, 28(1), 25-30.

NPC. (2004). Meeting everyone's Needs: National Economic Empowerment and Development Strategy, Nigerian National Planning Commission. Retrieved from http://www.siteresources.worldbank.org

Osunkeye. (2008). Global economic crisis and its implication for Nigeria, the Nigeria newspaper online publication. Retrieved from http://www.ngrguardiannews.com

Samaras, V. (2007). Internal versus external growth: impact on operational and Market Performance.

Sathye, M. (2002). The Impact of Foreign Banks on Market Concentration: The Case of India. Applied Econometrics and International Development, 2, 7-20.

Soludo, C. (2004). Guidelines and Incentives on Consolidation in the Nigerian Banking Industry. Thisday Newspaper, August 6.

Soludo, C. (2005). The Imperative of Banking Sector Reforms in Nigeria, Being Paper Presented at the Inauguration of the Consultative Committee on Banking Sectors Consolidation. Retrieved from http://www.CenBank.org

Somoye, R. (2008). The Performance of Commercial Banks in Post-Consolidation Period in Nigeria: An Empirical Review. European Journal of Economics, Finance and Administrative Science, 14.

Sudarsanam, S. (2003). Creating value from Mergers and acquisitions: The challenges. Harlow, Pearson Education Limited.

Thompson, S., \& Wright, M. (2005). Edith Penrose's contribution to Economics and Strategy: An overview. Managerial and Decision Economics, 26, 57-66. http://dx.doi.org/10.1002/mde.1216

Umah, G. (2009). Impact of the Banking Industry Recapitalization on Employment in Nigerian Banks. European Journal of Social Sciences, 11(3), 486-495.

Zenith Bank. (2011). Summary of 5 Years Annual Reports for the year ended 30th June, 2011.

Zikmund, W. G. (2003). Business Research Methods (7th ed.). South Western Australia, Thompson.

\section{Appendixes}

Appendix 1. Pre bank consolidation

\begin{tabular}{ccccc}
\hline Year & RGDP & M2 & INTRATE & EXR \\
\hline 2000 & 5.44398 & 48.0677 & 21.32 & 92.6934 \\
2001 & 8.45 & 27.0047 & 17.98 & 102.105 \\
2002 & 21.3475 & 21.5542 & 18.29 & 111.943 \\
2003 & 10.233 & 24.1137 & 24.85 & 120.97 \\
2004 & 10.4795 & 14.0236 & 20.71 & 129.357 \\
2005 & 6.51193 & 24.3533 & 19.18 & 133.5 \\
\hline
\end{tabular}


Appendix 2. Post bank consolidation

\begin{tabular}{ccccc}
\hline Year & RGDP & M2 & INTRATE & EXR \\
\hline 2006 & 6.03102 & 43.0949 & 17.95 & 132.147 \\
2007 & 6.44983 & 44.2395 & 17.26 & 128.652 \\
2008 & 6.40723 & 57.7856 & 16.94 & 125.833 \\
2009 & 6.29603 & 48.3733 & 15.1 & 118.861 \\
2010 & 6.2322 & -88.254 & 12.1 & 124.448 \\
2011 & 6.03453 & 36.2345 & 12 & 128.542 \\
\hline
\end{tabular}

\section{Copyrights}

Copyright for this article is retained by the author(s), with first publication rights granted to the journal.

This is an open-access article distributed under the terms and conditions of the Creative Commons Attribution license (http://creativecommons.org/licenses/by/3.0/). 